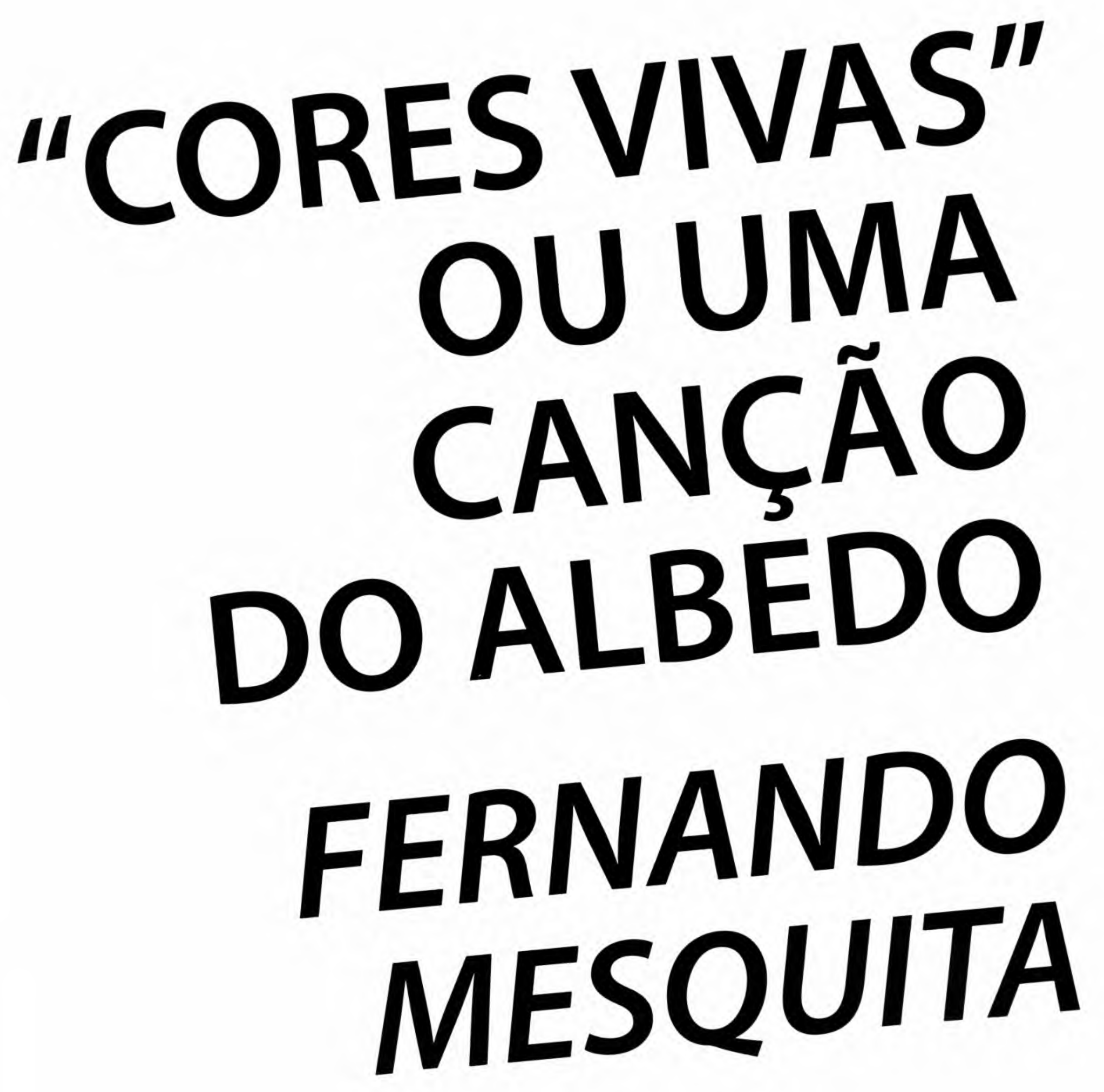


Resumo Este é o quarto dos dez ensaios que compõem A luz do sol da canção, tese sobre o simbolismo solar na canção popular brasileira contemporânea. Ao mesmo tempo em que se desenvolve uma análise formal baseada em conceitos fornecidos pela semiótica da canção de Luiz Tatit, busca-se evidenciar "passagens" entre a letra de "Cores vivas" e símbolos solares de civilizações tradicionais. Nesse contexto simbólico, a canção de Gilberto Gil é interpretada como uma celebração do "sol do meio-dia" pleno reinado da "luz branca" (Albedo). Palavras-chave Gilberto Gil; simbolismo solar; semiótica da canção.

Abstract This text is the fourth of ten essays which make up "A luz do sol da canção" [the sun's light song], a thesis on solar symbolism at Brazilian contemporary popular song. The essay develops a formal analysis based on the semiotic theory of Luiz Tatit and also shows links between "Cores vivas" [Live colours] and solar symbols founded on traditional civilizations. Gilberto Gil's song can be interpreted as a celebration of the midday sun, the realm of the "white light" (Albedo). Keywords solar symbolism; Gilberto Gil; the semiotic theory of song.

\section{CORES VIVAS}

Gilberto Gil

Tomar pé

Na maré desse verão

Esperar

Pelo entardecer Prescrição

Mergulhar

Na profunda sensaçāo

De gozar

Desse bom viver

Bom viver

Graças ao calor do Sol

Benfeitor

Dessa regiāo 
Natural

Da jangada, do coqueiral

Do pescador

\section{Contemplação}

De cor azul

Bela visão

Cartão-postal

Sabor do mel, vigor do sal

Cores da pena de pavão

Cenas de uma vibração total

\section{Cores vivas}

Eu penso em nós

Pobres mortais

Quantos verões

Meditação

Verão nossos

Olhares fãs

Fãs desses céus

Tão azuis ${ }^{1}$

1. Prescrição Os dois primeiros verbos da letra, "tomar (pé)" e "esperar", indicam preparação cuidadosa. E a assimilação do verão a uma maré esclarece contra qual risco é necessário cuidado: como é "sabido e repetido", nessa estação, o calor solar, no auge, pode arrastar desavisados e imprudentes para um "mar de sensações perigosas" $\mathrm{e}$ induzir atitudes que levem a um "afogamento do ser" ${ }^{2}$

1 Letra transcrita de Renno, Carlos (Org.). Gilberto Gil - todas as letras. $1^{\text {a }}$ ed. São Paulo: Companhia das Letras, 1996. p. 242.

2 O tema da influência estival na mudança de comportamento é, aliás, bastante freqüente: para ficar em alguns exemplos mais à mão, no cinema temos desde as inconseqüentes "loucuras de verão" de inúmeras comédias juvenis de Hollywood até a adaptação do clima denso e torturado criado por Tenessee Williams em De repente, no último verāo. Em "Tempo de estio", Caetano Veloso também aborda a exacerbação sensual do verão, fazendo nomes femininos continuamente passarem (fragmentados como corpos semi-nus) pelas frases melódicas e confessando:"Rio, eu quero suas meninas!"

$110 \neg$ MESQUITA, Fernando. "Cores Vivas" ou uma canção do Albedo 
Por isso, o observador-veranista, dotado de uma suposta competência acerca desses perigos, procura, a exemplo de um "salva-vidas existencial", instruir os demais veranistas sobre como "se comportar". Noutras palavras, o que está em jogo é o "adequado" /fazer/, ou melhor, por se tratar de "prescrição", o / dever fazer/ durante a estação. Mas, depois do refreamento representado por "tomar pé" e "esperar", ou seja, depois da "conscientização" dos cuidados prévios que evitam perigos, a instrução seguinte, "mergulhar / (na profunda sensação)", "libera" os veranistas para um gozo total do "bom viver" proporcionado pelo verão. Portanto, se há prudência, não se trata de prudência passiva, aquela dos timoratos e que sempre redunda em abstenção, mas de uma prudência ativa, a que ousa o desfrute - desde que com conhecimento, com savoir-faire.

Interessante notar que - como no caso de uma bula médica ou de uma receita culinária - os verbos dessa "instrução de como viver bem o verão" estão todos no infinitivo, indicando que a prescrição tem validade onitemporal e se dirige a todos os interessados, incluindo o próprio prescritor. Trata-se, portanto, de algo que tem o valor equivalente ao de um saber tradicional. ${ }^{3}$

3 Se ao invés do infinitivo, Gilberto Gil tivesse empregado, por exemplo, o pretérito perfeito,"Tomei pé/ Na maré desse verāo/Esperei / Pelo entardecer..." a experiência perderia totalmente o seu caráter "normativo"e se transformaria num relato pessoal.

Com respeito a esse viés "prescritivo" da obra de Gil, cabe aqui a recordação de um fato, já desbotado no tempo, mas bastante significativo. Por volta de 1974, o então (muito) jovem repórter Matinas Suzuki Jr.escreveu uma matéria, num tablóide alternativo, com este título-pergunta:"Gilberto Gil, um ditador no palco?" Em resumo, Matinas, dentro do influxo contestador da época, questionava o fato de Gil, nas suas apresentações, estimular e dirigir (a seu ver de maneira "autoritária") o público a dançar e cantar durante seus shows. A crítica a esse autoritarismo transbordava para as próprias cançōes de Gil, plenas (segundo o repórter) de pretensão de indicar como os jovens deviam pensar e agir. A matéria foi suficientemente incômoda para provocar uma resposta de Gil na forma de uma entrevista concedida ao próprio Matinas e publicada no número seguinte (como se vê, a coisa não deixava de ter uma função publicitária para o jornalzinho). Vista na perspectiva já bem longínqua de trinta anos, parece ficar claro que a crítica de Matinas - claro que nutrida da energia daqueles anos rebeldes - tocava exatamente nesse componente de "saber tradicional" da obra de Gil (e nada mais coerente que um jovem daqueles anos se rebelasse ao pressentir esse saber, ainda que transfigurado em cançōes)

Teresa revista de Literatura Brasileira [4 | 5]; Sào Paulo, p. 108-129, 2004. — 111 
Tomar pé

Na maré desse verão

Esperar

Pelo entardecer

Mergulhar

Na profunda sensação

De gozar

Desse bom viver

»Procurando explicar: a hipótese é que esse traço prescritivo de muitas das canções de Gil corresponde a uma ligaçāo rememorativa com a ascendência tribal africana. No universo tribal (os documentos antropológicos a respeito mostram que se trata de uma característica comum aos povos ágrafos), a sabedoria do viver está com os velhos da tribo e é oralmente comunicada aos jovens, através de conselhos e histórias ou nomeando a sua categoria geral, através de relatos de fundamento mítico. Por certo esse saber não é pessoal e sim provém da experiência imemorial do próprio povo codificada em formas condensadas (entre outras fontes, a sabedoria tradicional de um povo pode ser avaliada através dos seus provérbios). Como "tantas pontes cruzou um velho quanto ruas um jovem" (provérbio chinês), isto é, como a experiência dos velhos é incomensuravelmente maior que a dos jovens, as suas observações são consideradas ajuda preciosa no entendimento da vida e se colocam como fonte de autoridade. Esse saber sem autoria corresponde à experiência coletiva dos antigos; o papel dos velhos apenas é o de transmiti-lo (com inevitáveis inflexões pessoais) na mesma forma em que foi por eles recebido dos velhos do seu tempo de jovens. Aliás, não é preciso recuar à profundidade dos tempos míticos tribais ou aos arcaicos primórdios da civilizaçāo chinesa para se encontrar essa valorizaçāo da experiència; no seu Dicionário de sentenças latinas e gregas (São Paulo: Martins Fontes، 2000), Renzo Tosi enfileira uma série de provérbios e citações mostrando que esse topos, entre outros, está em Eurípides (292,2N,"melhores são os conselhos dos velhos") e na máxima de Publílio Siro (Q54) "Quod senior loquitur omnes consilium putant" " $\mathrm{O}$ que 0 velho diz todos consideram sensato") e que, do mundo greco-romano, passa para o medieval ('Senectus primumet anteiuvenes consulenda", "Os velhos devem ser consultados primeiro e antes dos jovens",Walther 28007C) prolongando-se até os dias atuais em provérbios modernos: En conseil écoutel homme age. Del rico es dar remédio y Del viejo consejo, Consiglio de Vecchio non rompe mai la testa etc. (cf. p. 306).

Mas no caso de Gil, o citado "pano de fundo" tribal se combina com um criador extremamente afinado com as transformações sociais e estéticas do seu tempo, ou seja, com um cancionista de vanguarda. Ao mesmo tempo em que observa com muita agudeza o "balé das modas e tipos" registrando em ato a emergência do novo (p. ex.,"Refavela","Punk da Periferia"), o compositor baiano não deixa de "meditar

$112 \neg$ MESQUITA, Fernando. "Cores Vivas" ou uma canção do Albedo 
Na relação entre as quatro estações e as quatro fases do dia, o verão (ou pelo menos o auge do verão) corresponde ao meio-dia. "Mergulhar/ na profunda sensação" dessa estação significa, portanto, instalar-se na "plenitude" do tempo estival e ver as cores como cores vivas à luz intensa do meio-dia. Dessa forma, quanto à questão dos "regimes de cores" (já abordada na análise de "Trem das cores", de Caetano Veloso ${ }^{4}$ ), na canção de Gil, em oposição às cores deslizantes e nuançadas da de Caetano, as cores serão fixas e vivas, quer dizer, vistas em estado de máxima satu-

》 cancionalmente" sobre os grandes temas permanentes da vida, muitas vezes no tom de um "velho da tribo" (basta lembrar "Andar com Fé"). Quando se dá uma fusão harmoniosa entre esses dois componentes - o estilo pessoal do criador imerso na confusāo "urbana, suburbana e rural" das cidades brasileiras e o"saber" geral de um velho africano que revém — isto dá origem a um tipo de canção personalíssima que, na falta de termo melhor, pode ser chamada de "os bosquejos de Gilberto Gil"."Bosquejar", em linguagem pictórica, se refere a "esboçar" "pintar sem determinar os contornos das figuras" Dicionário Caldas-Aulete. Rio de Janeiro: Delta, 1958, p. 716) mas "bosquejo" está aqui tomado no sentido figurado (mais freqüente no emprego lusitano e principalmente espanhol) de "descrição a largos traços, sem desenvolver os pensamentos". Refere-se a um traço típico de algumas canções de Gil: "Cores vivas", ao mesmo tempo em que se apropria do mais efêmero do tempo presente,"gozar o bom-viver" (e o que pode ser mais efêmero do que as modas do verão? Basta recordar, no Rio,"o verão da tanga do Gabeira,"'o verão do apitaço", etc.) é um "bosquejo sobre o verāo" que insere essa "matéria instantaneamente perecível" numa perspectiva "quase-metafísica", esboçada em versos que apenas sugerem uma "projeção transcendente" e convidam a um seguimento por conta do próprio ouvinte. Nesse último aspecto, o da "incompletude", os bosquejos de Gil retomam uma fórmula típica do pensamento tradicional, patente, por exemplo, nos provérbios. Todo provérbio é uma asserção geral, uma espécie de "equação algébrica" em forma sentenciosa cuja solução "aritmética" isto é, cuja aplicação "concreta em situaçōes concretas" depende da lucidez de cada aprendiz.

4 Constante de uma tese de doutorado sobre o simbolismo solar na obra de Caetano Veloso, esta análise de "Cores vivas" está colocada em contraste com "Trem das cores". Isto porque tomando-se a posiçāo do sol no céu como principio organizador do corpus cancional selecionado, "Cores vivas" aparece como uma cançāo "do meio dia" face a "Trem das cores", uma cançāo "auroral" Na análise, considerou-se que as cores da aurora se manifestam sob a influência de um "filtro vermelho", enquanto as do dia pleno se apresentam regidas por um "filtro branco."Estes dois filtros permitem a definição de dois "regimes" de cores que, por simples empréstimo do jargão alquímico, foram denominados respectivamente Rubedo e Albedo.

Teresa revista de Literatura Brasileira [4 | 5]; São Paulo, p. 108-129, 2004. r- 113 
ração sob o regime da "luz branca" característica do Albedo. De acordo com o verso de Guillén, as cores vivas do verão possuem a clareza de "um dia parado em su mediodia"

Instalar-se no cerne do tempo do verão e "gozar desse bom viver" significa vivê-lo sob o aspecto durativo. Se o verão é o "meio-dia" das estações, o outono, a estação imediatamente subseqüente, será o "crepúsculo". Por isso, viver durativamente o verão também pode ser expresso como "esperar/pelo entardecer"

A “instrução” inicial é precisa: “Tomar pé/ Na maré desse verão”. Quer dizer, definir um ponto fixo, um ponto de vista que permita observar as "cores vivas" mas que também seja um fundamento, um valor capaz de "dominar" beneficamente o fluxo de energia solar convertendo-o em atitudes "soberanas". Em síntese, "mergulhar/ na profunda sensação" sem perder o pé, esta a sabedoria do verão.

Em oposição à busca desse ponto fixo, "Trem das cores" realiza um assentimento total ao movimento: "a bordo de um trem, o observador semovente explora todas as 'janelas do olhar' com uma espontaneidade quase infantil, percorrendo um mundo em mutação" Já o observador-veranista de "Cores vivas" contempla a paisagem do seu "posto de observação" como uma bela visão de cartão postal, ou seja, como uma "imobilização instantânea do típico" (e, no limite, mesmo do pitoresco dotado de interesse turístico), uma cena na qual as cores primárias se contrastam sem nuanças numa estampa brilhante e vistosa. Vemos, então, que as duas canções realizam uma perfeita congruência entre o regime de cores (deslizantes/nuançadas num caso e fixas/simples no outro) e o ponto de vista do observador (semovente e variado, ou imóvel e angulado na totalidade).

Esse contraste também se dá no plano das emoções. Enquanto o observador-semovente de "Trem das cores" se deixa levar pela atmosfera do contemplado e imerge totalmente no sentimento nascente de um face a face, o observador-veranista mergulha e observa ao mesmo tempo não uma cena íntima, mas uma paisagem "geral" típica, vista à distância, o que é uma maneira de aderir sem se envolver totalmente (cabe dizer que, apesar do calor emocional do verão, há, na canção, um quê de distanciamento entre observador e paisagem). 


\section{Contemplação}

[...]

De gozar

Desse bom viver

\section{Bom viver}

Graças ao calor do Sol

[Sol] Benfeitor

Dessa região

[Regiāo] natural

[...]

Significativo notar que a passagem da primeira para a segunda estrofe se dá através de uma anadiplose e que, na seqüência, essa mesma figura ocorre mais duas vezes, se bem que de forma elíptica. Uma possível interpretação dessa presença é que a duplicação dos "elementos do verão" corresponde a uma ênfase ("aparecer e reaparecer") no aspecto durativo da canção. ${ }^{5}$

Quase não é preciso referir: a própria letra já apresenta o Sol, "benfeitor/dessa região", como dispensador de benefícios e, portanto, destinador dos "valores em jogo", ou, mais precisamente, destinador da luz e do calor.

5 "Anadiplose (do grego anadiplosis, reduplicaçāo): figura de linguagem, consiste na repetiçāo da última palavra de um segmento métrico (verso ou hemistíquio) ou sintático, no início do seguinte. [...] Exemplo:"O regedor das ithas que partia // Partia alegremente navegando" (Os Lusiadas, c. I, estr. 59/60)" (cf. MOrSES, Massaud. Dicionário de termos literários. São Paulo: Cultrix, 1974, p. 24). No seu Dicionário musical brasileiro, Mário de Andrade cita uma toada do sul de Minas, a "Toada das cinco dores": "Nascer pra depois viver, /Viver pra depois querer, / Querer pra depois não ter, / Não ter pra depois sofrer, / Sofrer pra depois morrer." (Itatiaia/Edusp, 1989, p. 518); nesta visão queixosa e pessimista, a vida é resumida em cinco etapas delusivas cuja continuação é articulada por anadiploses, reforçando a possibilidade de ligação entre essa figura e o aspecto temporal durativo. 
Na seqüência:

[...]

[Região] natural

Da jangada, do coqueiral

Do pescador

De cor azul

Bela visão

Cartão postal

[...]

Nestes versos (que literalmente compõem o "cartão postal") estão os elementos da típica "cena praieira" - corriqueira para os nativos, mas ao gosto do olhar visitante. Diferentemente do mundo pictórico de “Trem das cores", que é o mundo das "cores da estranheza", demandando por isso um enorme esforço nomenclatório ("oliva da nuvem chumbo ficando pra trás da manhã", "ouro ainda não bem verde da serra"), nesse mundo intenso de cores "vivas" é fácil percebê-las se dando nitidamente ao olhar na amplitude: a massa verde dos coqueiros ao vento na orla da praia, a vela branca das jangadas no mar. Tão nítidas à luz firme do verão, dir-se-ia que essas cores "nos entram pelos olhos"

Em contraste com os nomes das inúmeras cores nuançadas da canção auroral de Caetano, no mundo claro de "Cores vivas" apenas um nome de cor é proferido: azul. Precisamente o azul celeste do meio-dia estival, cor na qual estão subsumidas todas as outras. E quanto a esta cor geral sobredeterminando a paisagem, sua onipresença impõe a idiossincrasia de uma ordem inversa: "de cor azul / bela visão", recurso estilístico para enfatizar que a cor é o mais importante da visão. Cor, convém relembrar, que também aparece como índice físico do sol a pino. Na verdade, "azul celeste" quer dizer sol brilhando e é desse sol soberano, simbolizado na letra pelo pavão, que procedem as cores: 
Sabor do mel, vigor do sal

Cores da pena de pavão

Cenas de uma vibração total ${ }^{6}$

Essa "vibração total" do verão (da qual, aliás, o canto das cigarras é um símbolo maravilhoso na poesia de Manuel Bandeira) compõe-se necessariamente de luz e calor. Nesses três versos finais da "Contemplação", o "sabor do mel" e o "vigor do sal" comparecem como símbolos do "concentrado energético" do sol e representam a "essência" da vibração, enquanto as penas do pavão, por conterem todas as cores reveladas pela luz solar, dão conta do total. Dessa forma, calor e luz se traduzem em energia estuante e cores resplandecentes, valores com os quais (a exemplo das cores aurorais de "Trem das cores") o olhar do "veranista-observador" está em permanente conjunção eufórica.?

6 "O pavão é originário da Índia, onde, em razāo da roda suntuosa que por vezes as plumas da sua cauda formam, era símbolo do sol" (cf. Enciclopédie des symboles. Paris: Le Livre de Poche, 1996, p. 501)"O mesmo símbolo tradicional se apresenta em "Trilhos urbanos" de Caetano Veloso, na contemplaçāo do "Apolo (o Sol) e o rio Subaé/Pena de pavão de Khrishna/Maravilha vixe/Maria māe de Deus/Será que esses olhos são meus?"

7 Enquanto alimento físico, o mel é considerado pela simbólica tradicional um "fluido orgânico solar" ou, em termos taoístas, um alimento "essencialmente yang." Já o sal marinho, por redundar da evaporação das águas do mar pela açāo do sol, é considerado (L.C. Saint Martin) um "fogo liberto das águas" e, como tal, um "precipitado" também de natureza solar (cf. CHEVALIER, Jean e GHEERBRAN, Alain. Dicionário de símbolos. Rio de Janeiro: José Olympio, p. 797).

Além de ser um "território" privilegiado da luz e do calor, a praia é, por si só, um local onde o livre jogo dos "elementos naturais" eleva a energia ao máximo. Como se sabe, a cosmologia tradicional via o mundo material como composto por combinaçōes de quatro elementos "sutis" derivados do éter primordial: fogo, ar, água e terra. Ora, nas praias ao sol do verão os "representantes materiais" por excelência desses quatro elementos, raios de sol, ventos, águas do mar e areias interagem livremente em máxima intensidade.

Por isso mesmo, as praias, fontes do "bom viver", são cenários de "curas rituais" segundo cânones da medicina tradicional. Eis uma descrição feita por um estudioso da simbologia e da ritualística solares nas culturas eslavas: "A cura ritual, tal como observada por este autor, é repetida diariamente, uma vez por dia, durante duas semanas. Ela começa a cada manhā com um banho de sol de meia-hora nas costas do Mar Negro. Então, próximo ao meio-dia, o paciente percorre uma faixa de areia de uns trinta metros em direção

Teresa revista de Literatura Brasileira [4 | 5]; São Paulo, p. 108-129، 2004. -117 
Em "Trem das cores", a percepção das cores (em particular a do azul) tende à dessubstanciação, deixando entrever o trabalho de uma "imaginação aérea" que se realiza na síntese do sonoro, do diáfano e do móvel. Em "Cores vivas", como seria de se esperar (até pela presença do adjetivo vivas), a imaginação abandona a regência do sutil aéreo e vai numa direção oposta, intensifica-se ao máximo em imaginação chamejante de cores ardentes percebidas como "vibração total": a luz solar e o céu azul tornam-se uma luz e um céu quase corporais.

Num trecho de $L$ air et les songes impressionante pela acuidade, Bachelard assim descreve essa passagem do céu da imaginação aérea para o da imaginação chamejante sonora: “[...] Tonalizamos o azul do céu fazendo-o vibrar' como um cristal sonoro, enquanto que, para as almas verdadeiramente aéreas, ele só tem a tonalidade do sopro. Assim, numa sobrecarga de intensidade, a condessa de Noailles escreve (La domination, p. 203): 'O azul celeste está hoje tão forte que se o olharmos muito tempo, ele cega; ele crepita, ele turbilhona, ele se enche de gavinhas de ouro, de geada quente, de diamantes pontudos, radiosos, de flechas, moscas de prata ..."”

» a um lago salino, onde ele se desnuda e se cobre com uma camada de sedimentos retirados do leito do lago. O corpo deve ser coberto inteiramente da cabeça aos pés. A seguir, o paciente permanece nu face ao sol, em silêncio, com os braços estendidos, até que o barro seque e pequenas rachaduras comecem a aparecer. Ai ele se junta a outros no mesmo estágio no lago morno, no seio do qual ele se alegra e se agita enquanto a água derrete e retira o barro do seu corpo e o sol do meio-dia brilha diretamente sobre sua cabeça. A seguir ele sai do lago e fica ao sol e ao vento para secar. $O$ ato final se cumpre com o enxagüamento da boca e dos pés com água fresca

Claramente, está envolvida nesse ritual a manipulação mágica dos quatro elementos, fogo (= sol), terra (= barro), água (= lago), ar (= vento), com o objetivo de um renascimento e uma renovação metafóricos nos quais o paciente se torna um com a terra/barro retirada do leito do lago, deixa-a cair no lago/mar primordial e dele emerge renascido para se aquecer aos raios do sol vivificante imitando a maneira pela qual a terra foi criada, de acordo com o mito da emersão cosmogônica" (cf. PERKOwSKI, Jan L."The sun in slavic cultures."In: SINGH, Madanjeet (Org.) The sun in mith and art. London:Thames and Hudson, 1993.).

8 Cf.p. 187-8.

$118 \neg$ MESQUITA, Fernando. "Cores Vivas" ou uma cançāo do Albedo 


\section{Isotopias melódicas}

1

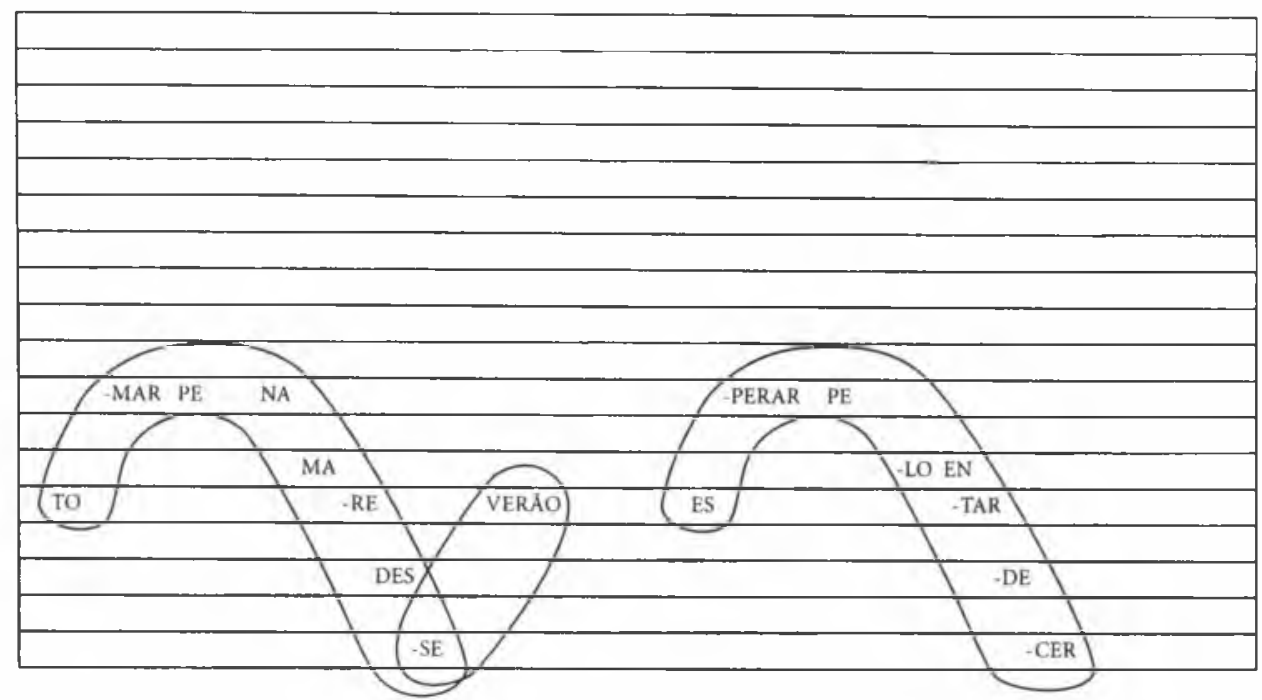

2

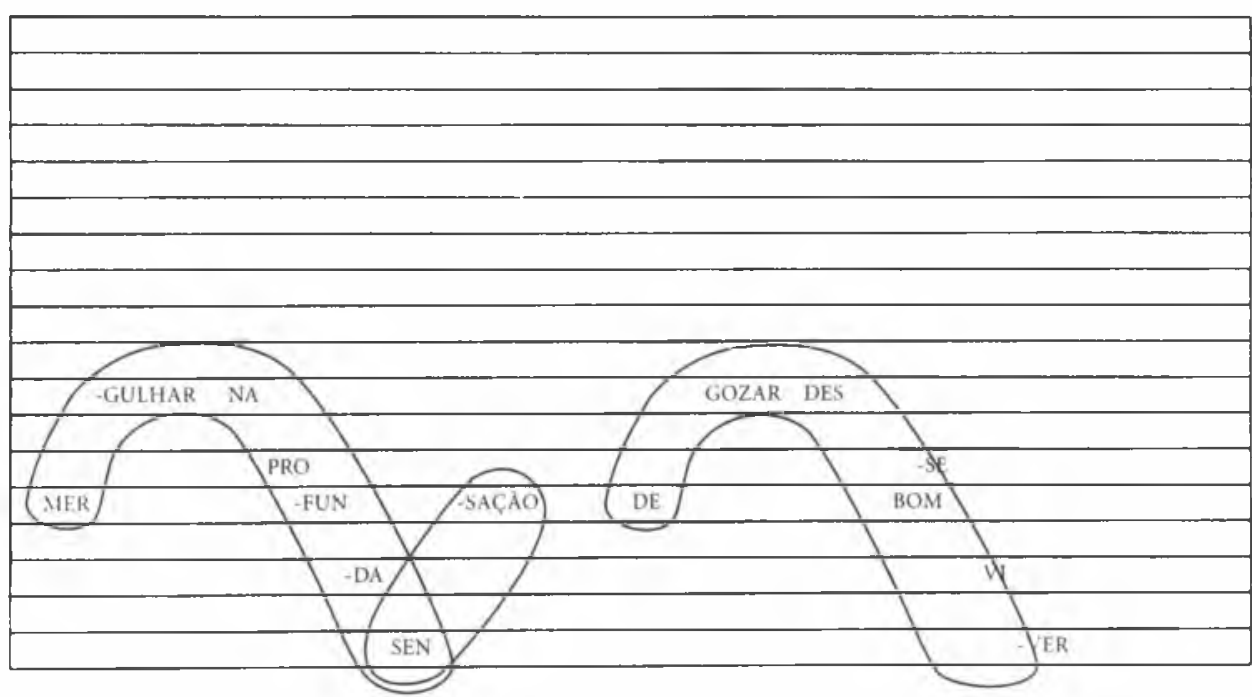

Do ponto de vista melódico, a "Prescrição" se completa em duas frases idênticas ("frases" melódicas 1 e 2). Cada uma apresenta o mesmo motivo repetido duas vezes, com um tonema prossecutivo (se-verão, sen-sação) servindo de enlace no trecho médio e terminando com um tonema conclusivo de 7 semitons (pe-loen-tarde-cer, des-se-bom-vi-ver) que traduz uma forte asseveração, típica do saber convicto ("verdadeiro e sem contestação") de toda prescrição. 


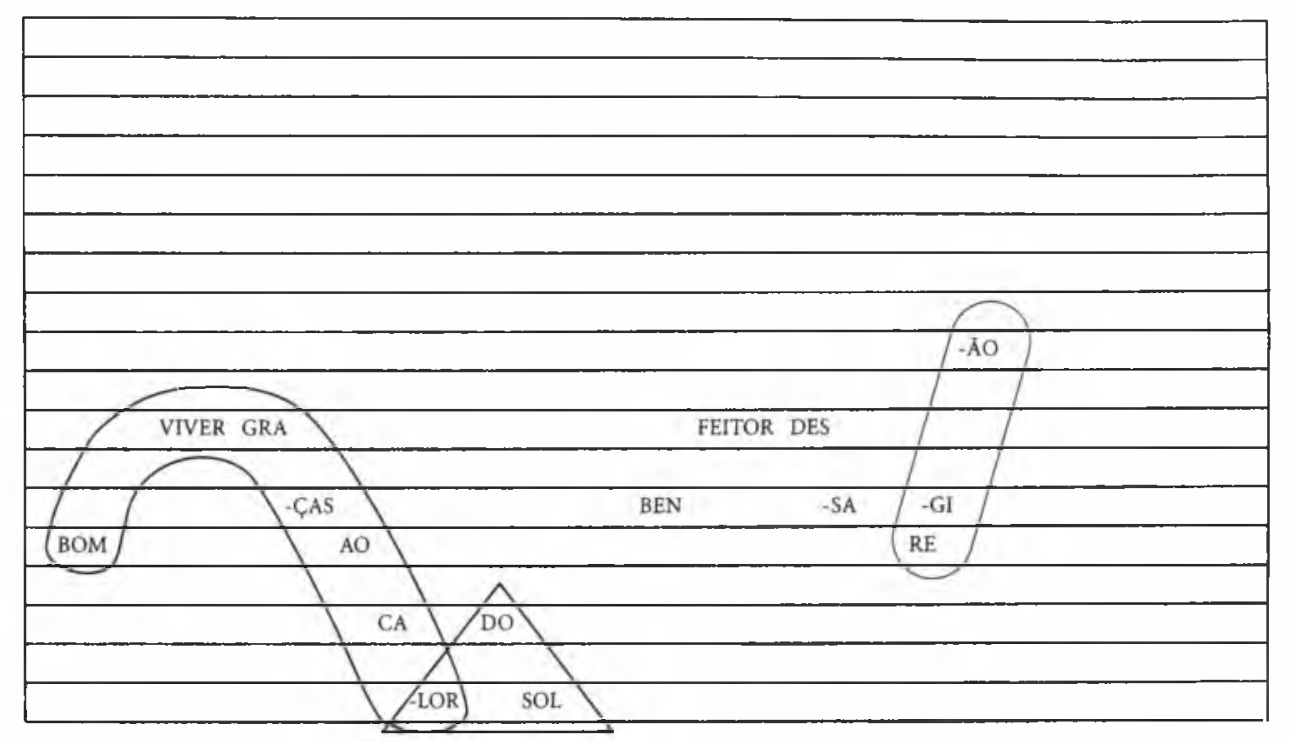

4

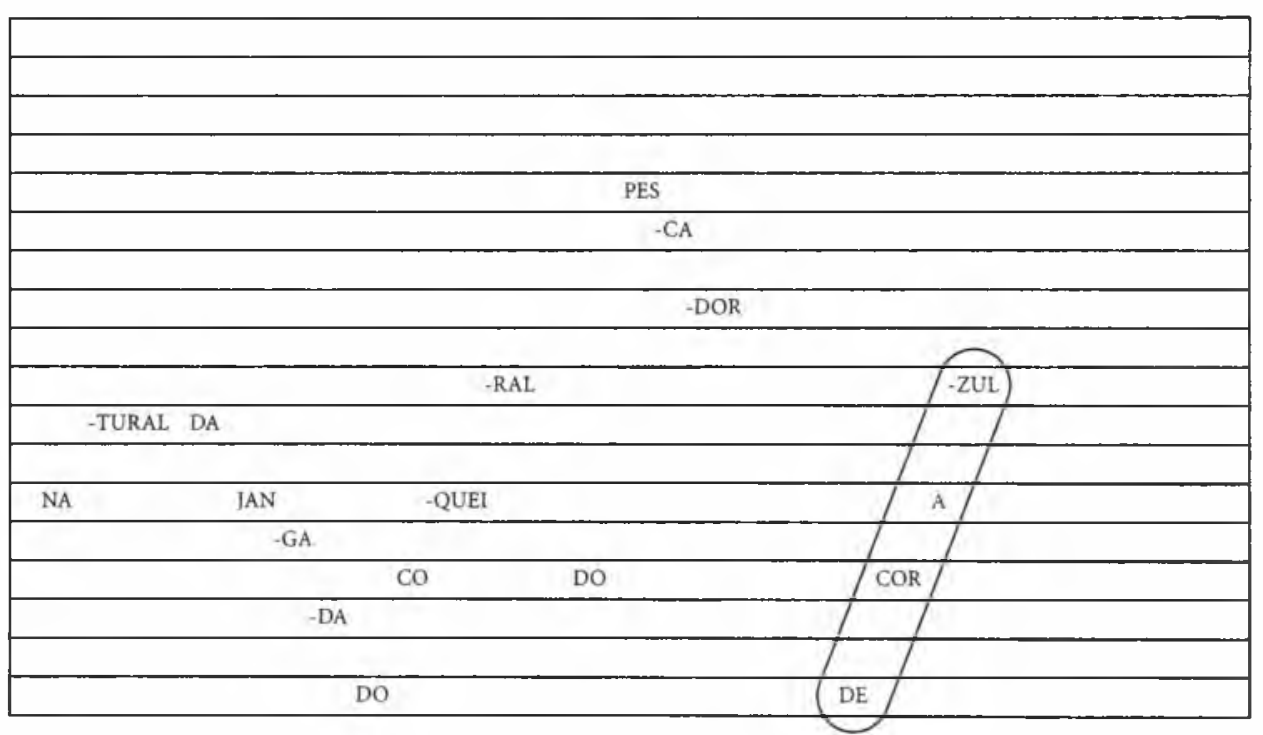

O mesmo motivo está na primeira metade da terceira frase, a que inicia a "Contemplação". Mas, a partir de lor-do-sol (tonema não mais prossecutivo e sim continuativo-conclusivo), o que se instala é um outro padrão: tanto re-gi-ão, tonema do final da terceira frase, como de-cor-a-zul, que compõe o final da quarta, são continuativos (uma ascensão de cinco semitons no primeiro e oito semitons no segundo) indicando um forte impulso à prossecução. Contrariamente à finalização peremptória das duas frases iniciais (como vimos, traço típico da prescrição), ago- 
ra o desfrute do "bom viver" (sob o calor do sol e em plena contemplação do "cartão postal" da paisagem) condiciona irresistivelmente o desejo de prosseguir numa conjunção "gozosa" com esses valores, ou seja, de perpetuar a duração do verão; daí, como foi assinalado, os dois tonemas continuativos.

5

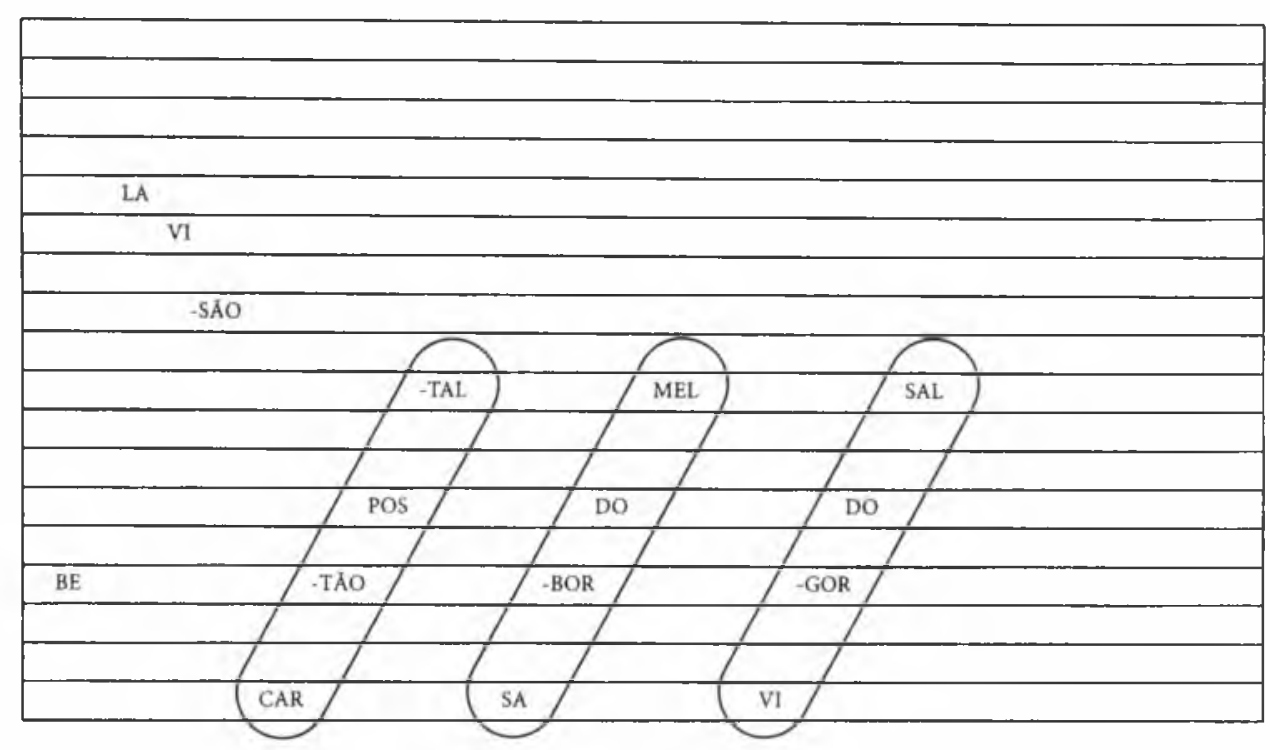

6

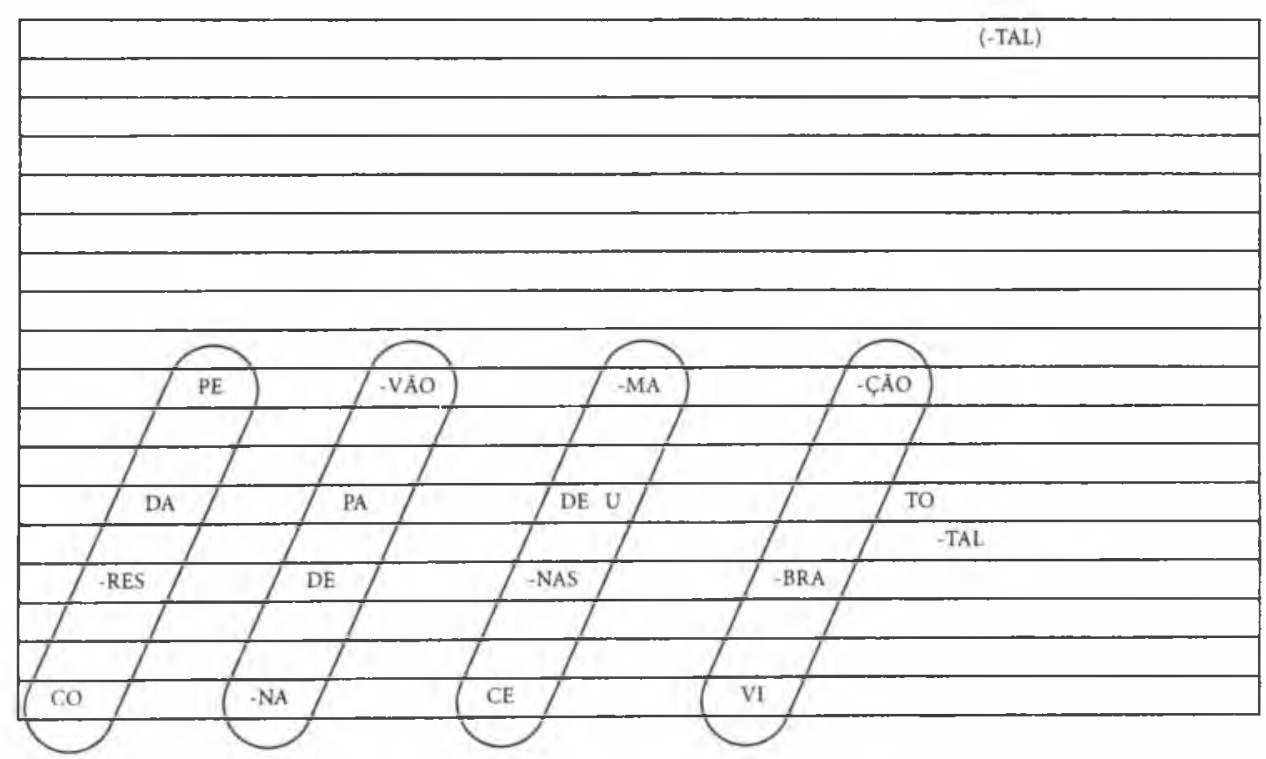

Esse "elã perpetuador" se intensifica e atinge proporções pletóricas no virtual "festival de prossecuções" que se desencadeia a partir do meio da quinta frase meló- 
dica, em car-tão-pos-tal, quando o mesmo motivo do tonema continuativo anterior (como foi observado, uma gradação ascendente de oito semitons) é repetido seis vezes (ou sete, se incluirmos a repetição imperfeita em vi-bra-ção) caracterizando uma tematização absoluta da continuidade.

Cabe referir que, no trecho inicial dessas repetições (diagrama 5, car-tão-pos-tal/ sa-bor-do-mel/vi-gor-do-sal), temos uma correspondência precisa entre melodia e letra, com o sentido desta se completando nos limites de cada gradação (notar, aliás, a rima interna entre sabor e vigor e o paralelismo entre as duas oxítonas monossilábicas terminadas em $l$, mel e sal, o que dá grande concisão expressiva ao verso; por outro lado, sal é rima de passagem entre cartão postal e vibração total (pares duplamente rimados), enquanto o $/ \mathrm{r} /$ de sabor e vigor ecoa o $/ \mathrm{r} /$ intermediário de cartão e ecoará, por sua vez, no dígrafo também mediano de vibração). Mas, nas duas repetições iniciais da frase 6, o sentido da letra se quebra em co-res-da-pe/ na-de-pa-vão transbordando para a gradação seguinte (numa operação correspondente ao enjambement poético), enquanto a repetição do motivo melódico ascendente se mantém. Isto quer dizer que o desejo de continuidade desenhado pela melodia prevalece sobre a "inteligibilidade da paisagem": tudo o que se quer do verão é que (repetição do motivo) ele continue indefinidamente, realizando, assim, a sensação utópica de que "o sol nunca mais vai se pôr" cantada por Chico Buarque ("Bye bye, Brasil”).

\section{Meditação}

4

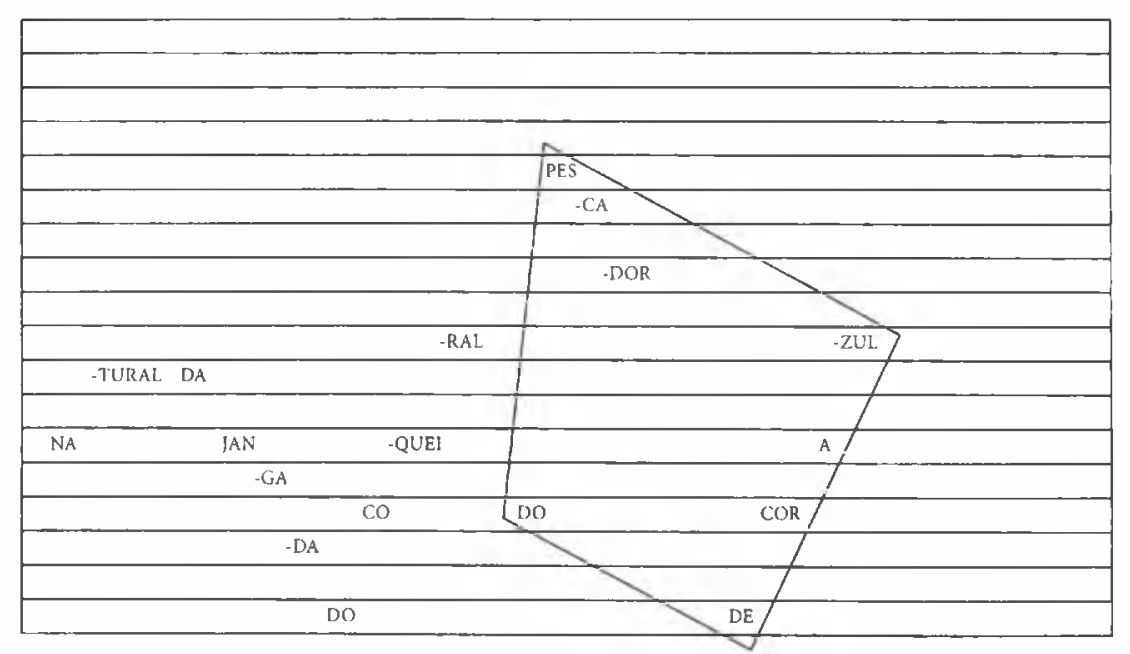


5

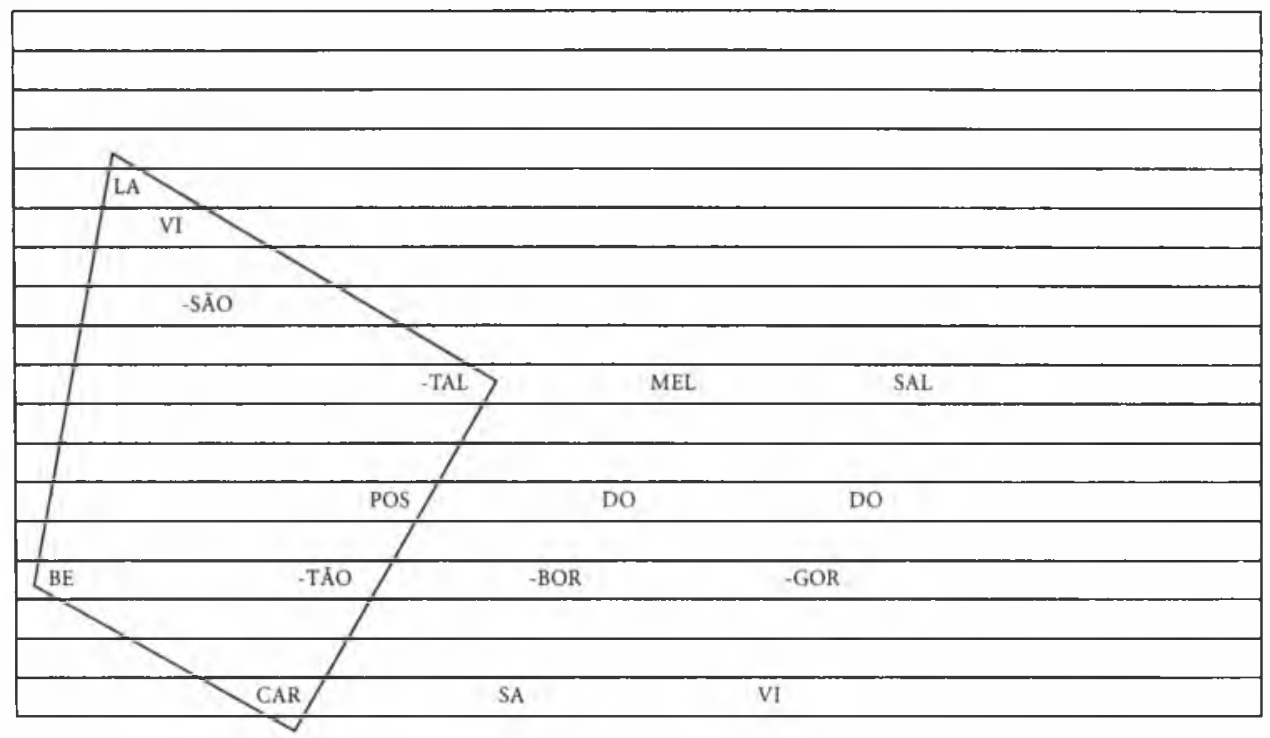

7

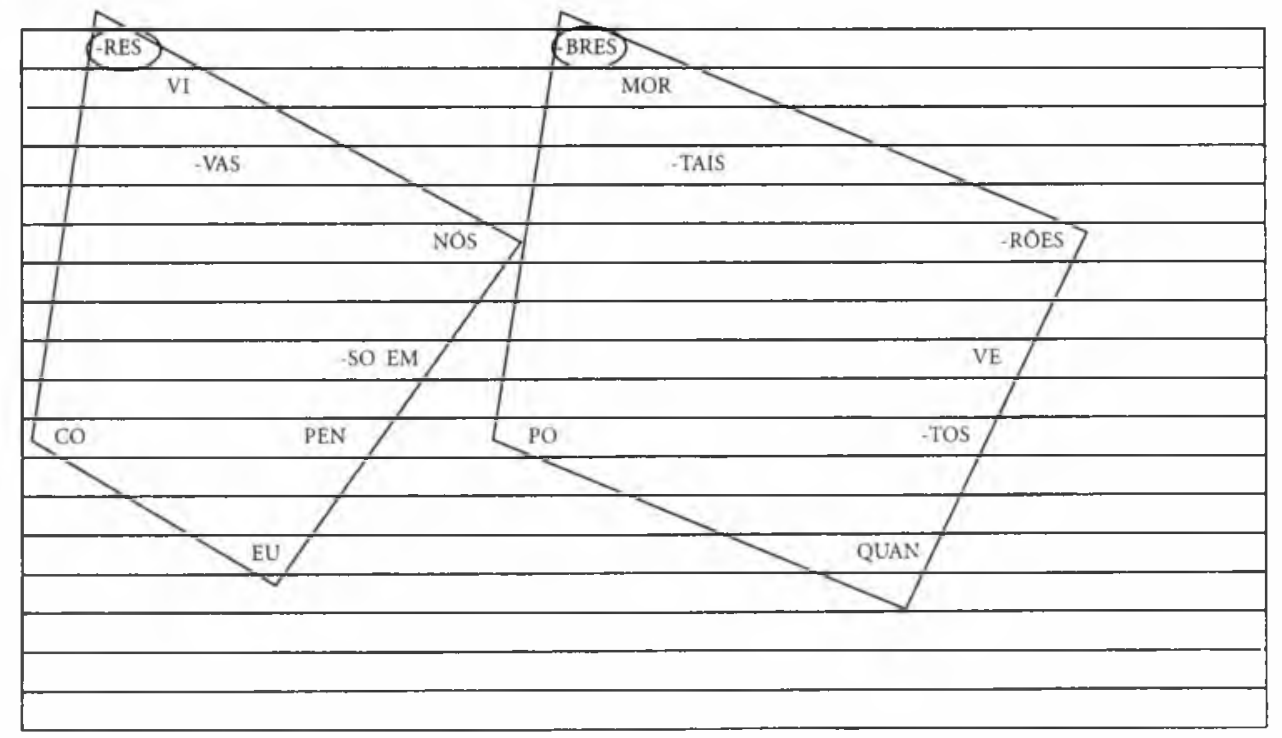

Teresa revista de Literatura Brasileira [4 | 5]; São Paulo, p. 108-129, 2004. $\ulcorner 123$ 


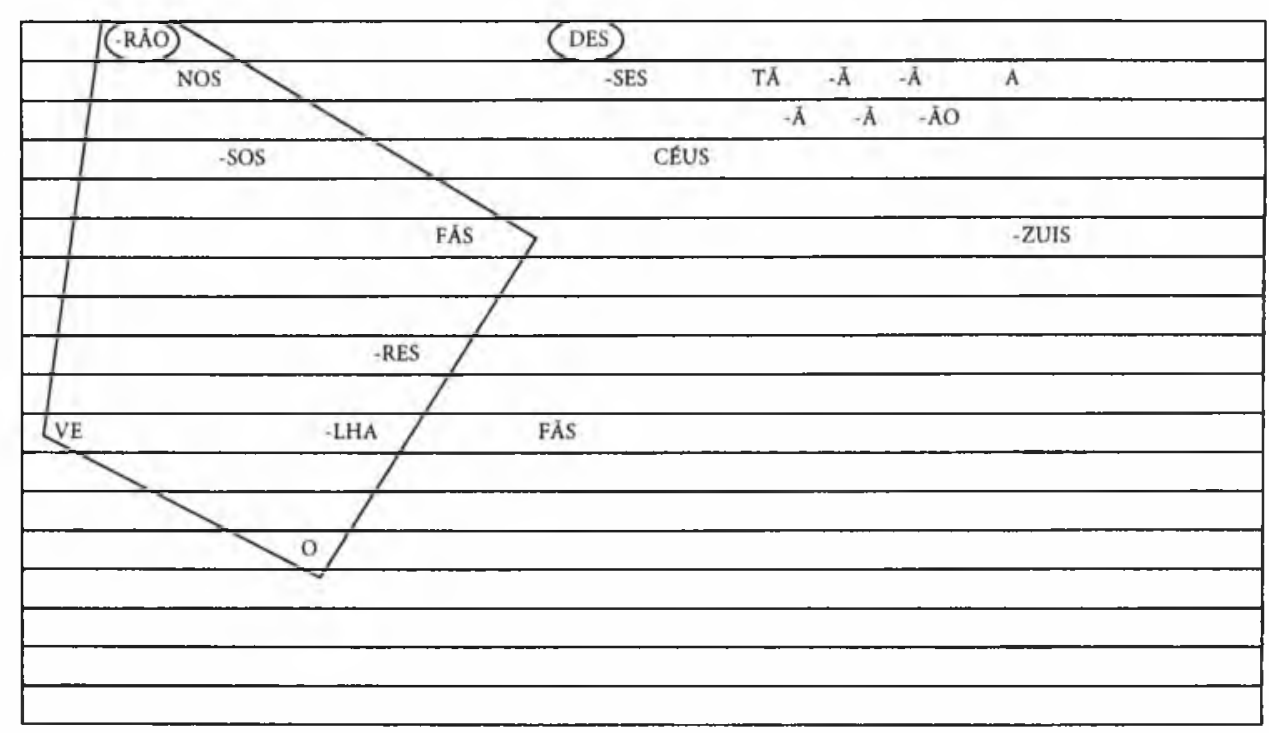

Como está assinalado acima, na passagem entre as frases 4 e 5 repete-se um pequeno "tema passional" composto por dois motivos: um salto melódico de dez semitons (do-pes e be-la) seguido de um curto tonema continuativo-conclusivo de três semitons em ca-dor e $v i$-são e a já citada gradação ascendente de oito semitons (3-2-3) em de-cor-a-zul e car-tão-pos-tal. Este tema reaparece três vezes na "Meditação" final (frases 7 e 8), só que deslocado quatro semitons para a zona aguda, o que indica aumento de tensão emocional na "reflexão" final (o pico melódico agudo da canção é então atingido quatro vezes na seqüência -res, -bres, -rão e des-).

No plano da letra, temos uma anadiplose perfeita em "olhares fãs / fãs desses céus" e outra imperfeita em "quantos verōes / verão nossos" Como vimos, na "Contemplação" o observador-veranista focaliza a paisagem objetivamente, considerada (ao longe) na totalidade dos seus elementos "folclóricos": jangada, coqueiral, pescador. Já na "Meditação", essa atenção exteroceptiva se rompe; um elemento "perturbador" entra em cena, fazendo com que a atenção do observador oscile num vai-e-vem entre a paisagem e a sua subjetividade (aliás, podemos interpretar que a tensão emocional da entrada desse "elemento" se expressa no plano melódico pela citada elevação da altura do tema):

"Cores vivas" - paisagem

"Eu penso em nós/pobres mortais" — subjetividade 
"Quantos verōes" — paisagem

"Verão nossos / olhares fãs" - subjetividade

"Fãs desses céus / tão azuis" - paisagem

A fratura entre paisagem e subjetividade causada pelo advento desse elemento altera a natureza das anadiploses:

CONTEMPLAÇÃO

[...]

De gozar

Desse bom viver

Bom viver

Graças ao calor do Sol

[Sol] Benfeitor

Dessa região

[Região] natural

[...]
MEDITAÇÃo

Cores vivas

Eu penso em nós

Pobres mortais

Quantos verões

- Verão nossos

Olhares fãs

Fãs desses céus

Tão azuis

$\mathrm{Na}$ "Contemplação", os três elementos que se repetem (o primeiro, explicitamente e os dois últimos de forma implícita), a saber, bom viver, Sol e regiāo, aparecem e reaparecem como substantivos. Na "Meditação", verão (na forma plural verões) aparece inicialmente como substantivo (nome da estação) referindo-se ao universo da paisagem e reaparece como verbo (verão, terceira pessoa do plural do futuro do verbo ver) quando inserido no universo subjetivo. Da mesma forma, fãs aparece inicialmente como qualificativo de olhares e volta como substantivo indicando um elemento da paisagem (os aficionados do céu azul). ${ }^{9}$

Essa mudança de natureza permite a seguinte interpretação: na "Contemplaçāo" (toda ela feita em "estado de bom viver") a harmonia ou unidade proprioceptiva

9 No caso,"elemento da paisagem praieira" no mesmo sentido em que os "fās" de um cantor fazem parte da "paisagem" de um show musical. 
entre olhar e paisagem se expressa numa permanência substantiva (ou seja, de coisa intemporal) dessa união. Na "Meditação", consumada uma ruptura entre olhar e paisagem (causada, como veremos, pela angústia da súbita percepção do tempo passando), a oscilação para diferentes campos de atenção (exteroceptivo e interoceptivo) por um lado mantém a substantividade dos elementos externos da paisagem (a indiferença das coisas impassiveis ao tempo) mas, por outro, remete os elementos subjetivos para categorias gramaticais (verbo e qualificativo) que expressam o tempo passando e suas modificações.

Na letra, não é difícil "rastrear" a gênese desse "elemento perturbador": enquanto o auge do verão transparece nas "cores vivas" das "cenas de uma vibração total", a consciência do tempo passando se infiltra na subjetividade do contemplador, recordando-lhe que "não há bem que sempre dure" e tornando presente a inevitável finitude das "coisas vivas". Assim, o vivas das cores convoca a sua negação, o mortais de "pobres mortais", e a plenitude lurninosa da duração estival começa a registrar a pequena sombra de uma inquietação terminativa: quanto tempo ainda, "quantos verões"? No plano objetal o verão ainda brilha com firmeza, mas no subjetal o outono já se insinua; transpondo para as "idades do homem", viver o "verão" (a juventude) com consciência de finitude é saber que durante "se espera pelo entardecer", isto é, caminha-se inelutavelmente para a maturidade (ou, se quisermos, para o começo da velhice).

Esse jogo entre lucidez e fruição fica claro se considerarmos o percurso tensivo da canção, ou seja, os diferentes "esquemas tensivos" que presidem as suas três partes: Na "Prescrição", a própria finalidade do discurso ("aconselhar") condiciona uma preeminência da cognição; temos uma dominância total do descortino (saisie) e o esquema tensivo posto em ação é o da decadência (alto nível de cognição e emoção rebaixada). E, como vimos, em consonância com o "prescrever", as curvas melódicas do trecho (frases 1 e 2) assumem um "perfil" fortemente asseverativo.

Na "Contemplação", o descortino da paisagem compreendida em toda a sua extensão ("compreender" tanto no sentido de "conhecer" como no de "abarcar com os olhos") coexiste com o mergulho na "sensação / de gozar / desse bom viver" esti-

10 A respeito, ver fontANILle, Jacques." Les schemas de tension". In: Sémiotique du discours. Limoges: Pulim, 1998, p. 103-9.

$126 \neg$ MESQUITA, Fernando. “Cores Vivas" ou uma canção do Albedo 
val, objeto de uma intensa visada (visée); emoção e conhecimento (ou intensidade e extensão) simultaneamente majorados convocam o esquema tensivo de amplificação (alto nível de cognição e de sensibilização). A melodia assume a dinâmica de uma tematização passional com forte ênfase, em termos aspectuais, na duração: como vimos, ocorrem sete repetições sucessivas de um mesmo motivo ascendente (tonema continuativo). Esse desejo de continuidade chega mesmo a alterar o perfil do tonema final da frase 6 , a última do trecho.

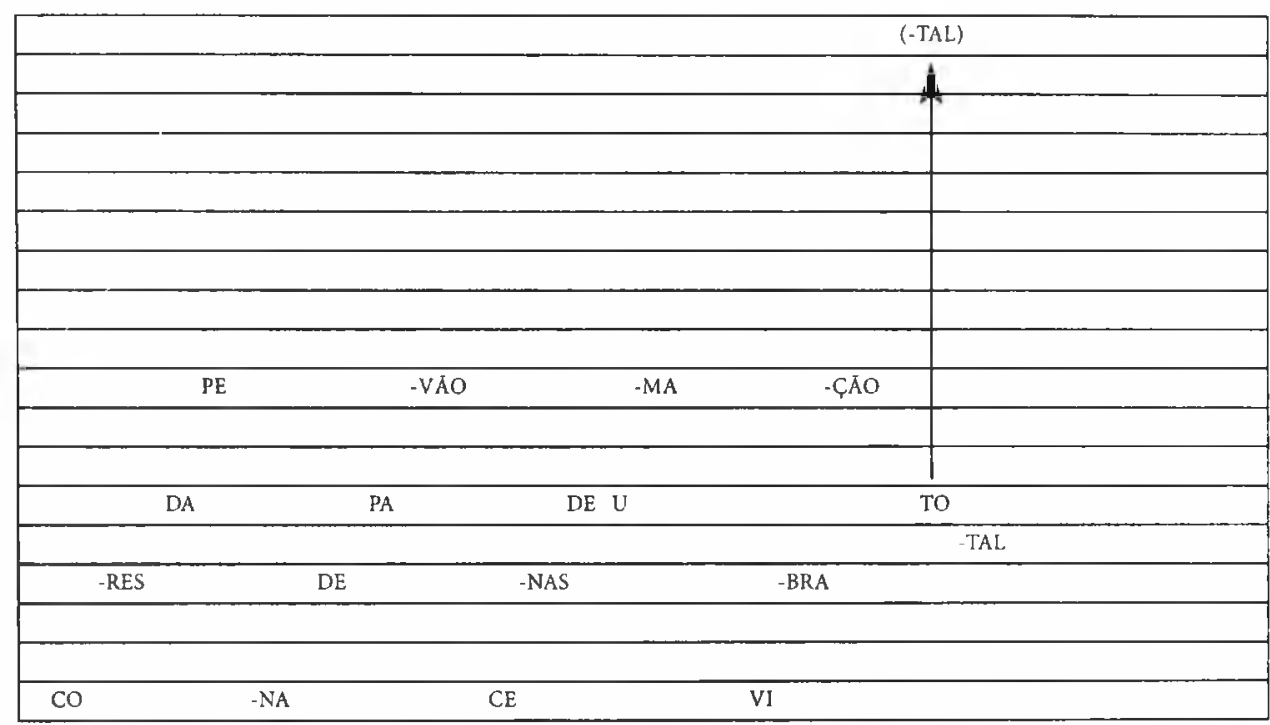

Na interpretação do próprio Gil (CD Luar, faixa 7), na primeira "passada" (execução inicial), to-tal é cantado de forma terminativa, com uma levíssima descida de meio tom. Na segunda (execução final), entre to- e tal ocorre um imenso salto de doze semitons (o maior da cançāo) transformando o que era um "discreto" término numa intensa volição de prosseguir.

O fato de a consciência da finitude se apresentar nos versos iniciais da "Meditação" poderia levar a um rebaixamento melancólico da emoção, reintroduzindo o esquema tensivo de decadência ocorrido na "Prescrição". Mas ao contrário: a elevação geral da altura do trecho (atingindo quatro vezes o pico melódico), ligada ao citado "pequeno tema passional" repetido três vezes, atua como um poderoso contrapeso sensível, mantendo assim o esquema tensivo de ampliação. Tudo se passa como se a "consciência da inevitabilidade do fim" tornasse o presente mais precioso ainda e, por isso, alvo da mais intensa celebração (aliás, o fato de os olhares serem fãs atesta que a admiração e a emoção estão de fato elevadas ao máximo 
grau). Como resultado dessa compensação, temos um curioso tonema final "quase suspensivo", todo ele na zona aguda e distendido num sinuoso tã-a -ãa-ã-ã-ão antes da terminação $a$-zuis.

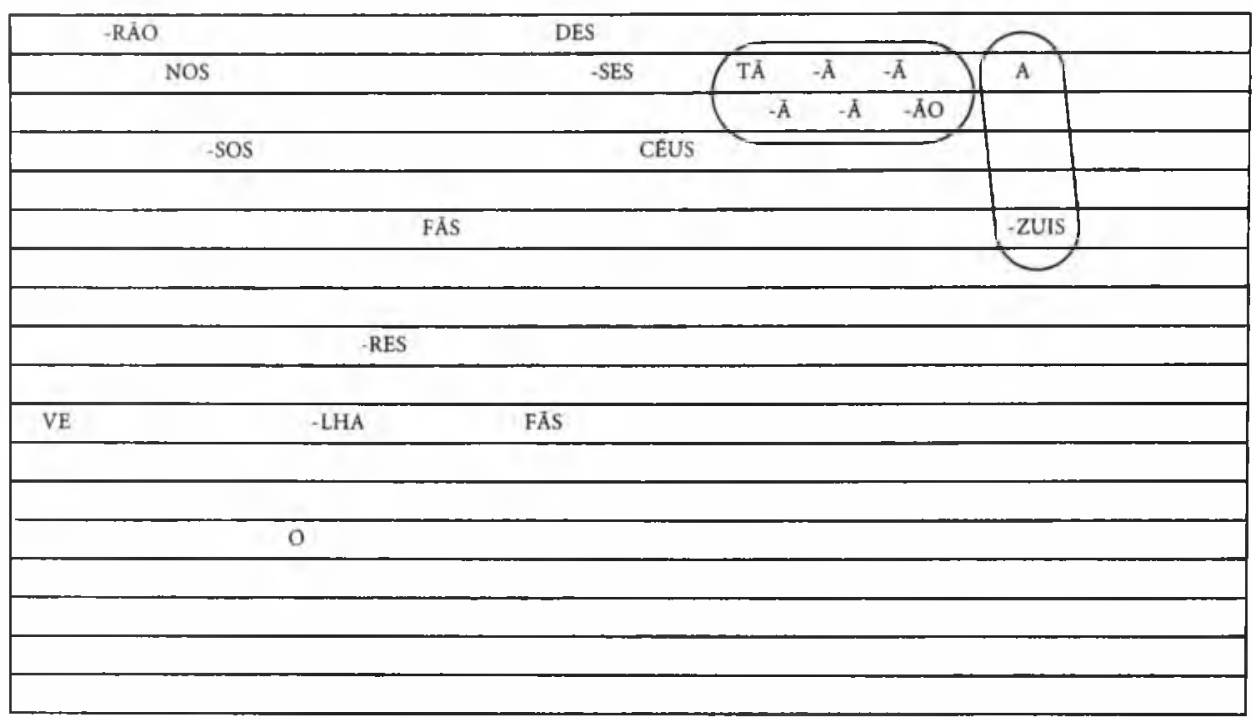

A exemplo do sucedido na "Contemplação", Gil, na segunda "passada" da letra, prolonga notavelmente o $t \tilde{a}-\tilde{a}-\tilde{a}-\tilde{a}-\tilde{a}-\tilde{a}-\tilde{a}-\tilde{a}-\tilde{a}-\tilde{a} o$ (uma duração duas vezes maior que a da primeira vez) e essa passionalização emissiva transborda para as vogais da última palavra, $a-a-a-a-z u u u-i s$, como se esse prolongamento consumasse a "fruição durativa" até a última gota do verão. Enquanto "Trem das cores", tendo como tema a felicidade, se instala serenamente numa duração sem bordas, "Cores vivas" é uma ensolarada canção sobre o Carpe diem.

Pode ser que de golpe

ao abrires a janela para a esplêndida manhã

te invada o temor:

"um dia não mais estarei presente à festa da vida"

Mas que pode a morte em face do céu azul?

Do escândalo do verão?

[...]

Teu coração,

esse mínimo pulsar dentro da Via Láctea, em meio a tempestades solares, 
quando se deterá?

Não o sabes poís a natureza ama se ocultar.

E é melhor que não o saibas

para que seja por mais tempo doce em teu rosto

a brisa deste dia

e continues a executar

sem partitura

a sinfonia do verão como parte que és

dessa orquestra regida pelo sol.

(Ferreira Gullar, "Morrer no Rio

de Janeiro" em Toda poesia)

Fernando Mesquita é doutor em Literatura Brasileira pela Universidade de São Paulo e professor da Universidade Estadual de Mato Grosso — UNEMAT (fernanmesquita@uol.com.br). 